\section{OPEN ACCESS}

Edited by:

Barbara Morgan,

University of Wisconsin-Madison, USA

Reviewed by:

Naoto Fujii,

University of Ottawa, Canada

Shane A. Phillips,

University of Illinois at Chicago, USA

*Correspondence:

Rosa Mancinelli r.mancinelli@unich.it

Specialty section:

This article was submitted to

Exercise Physiology,

a section of the journal

Frontiers in Physiology

Received: 23 September 2015 Accepted: 07 December 2015 Published: 24 December 2015

Citation:

Pietrangelo T, Di Filippo ES, Mancinelli R, Doria C, Rotini A, Fanò-Illic $G$ and Fulle S (2015) Low Intensity Exercise Training Improves

Skeletal Muscle Regeneration Potential. Front. Physiol. 6:399 doi: 10.3389/fphys.2015.00399

\title{
Low Intensity Exercise Training Improves Skeletal Muscle Regeneration Potential
}

\begin{abstract}
Tiziana Pietrangelo 1,2,3,4, Ester S. Di Filippo ${ }^{1,3,4}$, Rosa Mancinelli 1, 3,4*, Christian Doria ${ }^{1,2,4}$, Alessio Rotini ${ }^{1,4}$, Giorgio Fanò-Illic ${ }^{2,3,4}$ and Stefania Fulle ${ }^{1,2,3,4}$

${ }^{1}$ Department of Neuroscience, Imaging and Clinical Sciences, University "G. d'Annunzio" Chieti-Pescara, Chieti, Italy, ${ }^{2}$ Laboratory of Functional Evaluation, "G. d'Annunzio" University of Chieti-Pescara, Chieti, Italy, ${ }^{3}$ Centre for Aging Sciences, d'Annunzio Foundation, Chieti, Italy, ${ }^{4}$ Department of Neuroscience, Imaging and Clinical Sciences, Interuniversity Institute of Myology, Chieti, Italy
\end{abstract}

Purpose: The aim of this study was to determine whether 12 days of low-to-moderate exercise training at low altitude (598 $\mathrm{m}$ a.s.l.) improves skeletal muscle regeneration in sedentary adult women.

Methods: Satellite cells were obtained from the vastus lateralis skeletal muscle of seven women before and after this exercise training at low altitude. They were investigated for differentiation aspects, superoxide anion production, antioxidant enzymes, mitochondrial potential variation after a depolarizing insult, intracellular $\mathrm{Ca}^{2+}$ concentrations, and micro (mi)RNA expression (miR-1, miR-133, miR-206).

Results: In these myogenic populations of adult stem cells, those obtained after exercise training, showed increased Fusion Index and intracellular $\mathrm{Ca}^{2+}$ concentrations. This exercise training also generally reduced superoxide anion production in cells (by 12-67\%), although not in two women, where there was an increase of $\sim 15 \%$ along with a reduced superoxide dismutase activity. miRNA expression showed an exercise-induced epigenetic transcription profile that was specific according to the reduced or increased superoxide anion production of the cells.

Conclusions: The present study shows that low-to-moderate exercise training at low altitude improves the regenerative capacity of skeletal muscle in adult women. The differentiation of cells was favored by increased intracellular calcium concentration and increased the fusion index. This low-to-moderate training at low altitude also depicted the epigenetic signature of cells.

Keywords: low-to-moderate intensity exercise training, satellite cells, superoxide anion, oxidative status, miRNA, women

\section{INTRODUCTION}

Satellite cells are myogenic cells that are responsible for postnatal skeletal muscle growth. In normal adult muscle, satellite cells account for differently activated peripheral sub-sarcolemmal nuclei, which depend on the metabolic properties of the muscle fiber and the age of the person (Verdijk et al., 2014). In response to various stimuli, satellite cells can enter the mitotic cycle, proliferate, and fuse, thereby contributing to muscle regeneration for repair or hypertrophy of postnatal 
skeletal muscle (Lorenzon et al., 2004; Snijders et al., 2012; Ceafalan et al., 2014). Satellite cells are specifically involved in skeletal muscle adaptation to different types of exercise, such as with strength (Kvorning et al., 2014; Verdijk et al., 2014) and endurance (Kadi et al., 2004) training, whereby the intensity and duration of muscle stimulation is crucial for satellite cell activation. Indeed, although it has been demonstrated that satellite cells are not activated in response to a single bout of exercise (Kadi et al., 2004), they can modulate specific factor content after $9 \mathrm{~h}$ of combined resistance-endurance exercise (Verdijk, 2014). Furthermore, even if it is currently accepted that exercise has positive effects on skeletal muscle regeneration, the fitness level of subjects and the type and intensity of exercise protocols have crucial roles in satellite cell activation. In fact, a number of study demonstrated that both resistance and endurance training increased satellite cells content (Kadi et al., 2005). At the ultrastructural level, it has been observed that the endurance-training programme induced the formation of new myotubes (Appell et al., 1988). However, there are many points to be addressed at molecular level. The $\left[\mathrm{Ca}^{2+}\right] \mathrm{i}$ increase is a prerequisite for fusion process due to specific signaling it activates (Millay et al., 2013; Hindi et al., 2013). In fact, many studies have shown that myoblast fusion is regulated by $\left[\mathrm{Ca}^{2+}\right] \mathrm{i}$ increase (Constantin et al., 1996) that may depend on cholinergic (Bernareggi et al., 2012), stretch-activated and KCa channels activation (Pietrangelo et al., 2006; Shin et al., 1996).

Another molecular messenger influenced by exercise is reactive oxygen species (ROS) production (Abruzzo et al., 2013). The ROS include: superoxide anions, hydroxyl radicals, oxide anions, hydrogen peroxide, nitric oxide, peroxynitrite, lipid peroxyls, and lipid alkoxyls. ROS production is related to with the term oxidative stress, which was originally defined as "a disturbance in the pro-oxidant/anti-oxidant balance in favor of the former" (Siens and Cadenas, 1985). However, due to the complexity of the cellular redox balance, this was refined to "an imbalance between oxidants and anti-oxidants in favor of the oxidants, leading to a disruption of redox signaling and control and/or molecular damage" (Siens and Jones, 2007; Powers et al., 2011).

The cellular antioxidant system consists on the activity of scavengers as vitamin $\mathrm{C}$ and $\mathrm{E}$, for instance, and enzymes as glutathione peroxidase, superoxide dismutase (SOD), catalase (Cat). In particular, the SOD reduces the superoxide anion to hydrogen peroxide and in turn the Cat reduces this to water. There are several studies accounting for the involvement of antioxidant enzymes in exercise-induced muscle plasticity and also in vitamin supplementation (Cumming et al., 2014; Nikolaidis et al., 2015). However, it is not well understood the role of antioxidants in human myogenesis.

\footnotetext{
Abbreviations: a.s.l., altitude sea level; $\left[\mathrm{Ca}^{2+}\right]_{\mathrm{i}}$, intracellular calcium concentration; Cat, catalase; DCF-DA, $2^{\prime}, 7^{\prime}$ Dichlorodihydrofluorescein diacetate; JC-1,5,5',6,6'-Tetrachloro-1, $1^{\prime}, 3,3^{\prime}$ tetraethylbenzimidazolylcarbocyanine; $\mathrm{H}_{2} \mathrm{O}_{2}$, hydrogen peroxide; iodide/chloride; MHC, Myosin Heavy Chain; miRNA, micro ribonucleic acid; $\mathrm{O}_{2}^{\bullet-}$, superoxide anion; PBS, Dulbecco's phosphate-buffered saline; ROS, Reactive oxygen species; SOD, superoxide dismutase.
}

In mitochondria the cellular aerobic metabolism reduces around $1-2 \%$ of oxygen to superoxide anions, which represent the most abundant free radicals produced. The superoxide reactivity could last for days in absence of enzymatic removal and it can spread out into also outside the cell, and undergo reactions far from its site of production, thus provoking cellular and general oxidative stress. However, a gender distinguish has to be considered, as female subjects are more protected than men against oxidative stress thanks to their estrogen hormone. The estrogen level in young woman exerts an antioxidant effect, as demonstrated by four-fold less DNA and lipid oxidation in female with respect to male subjects (Mecocci et al., 1999; Green and Simpkins, 2000).

Skeletal muscle contraction during exercise produces variable amounts of ROS, which depend on exercise intensity and duration (Fisher-Wellman and Bloomer, 2009; Powers et al., 2011). ROS can activate specific signaling pathways at the plasma membrane and/or stimulate gene transcription (Gundersen, 2011; Baar, 2014). In particular, recent literature suggests that both exercise and ROS can activate muscle-specific microRNAs (myo-miRs; small post-transcriptional RNAs), and regulate the differentiation levels of satellite cells (Eisenberg et al., 2009; Crippa et al., 2012; Huang et al., 2012). Among the myo-miRs of value for satellite cells, there are miR-1, miR-133, and miR-206 (Kwon et al., 2005; McCarthy and Esser, 2007; La Rovere et al., 2014).

The aim of this study was to determine whether 12-day exercise training at low altitude (598 $\mathrm{m}$ a.s.l.) can improve skeletal muscle regeneration in adult women. In particular, we investigated whether this kind of exercise could affect some molecular actor of the differentiation process as the fusion index, the intracellular calcium level, the redox balance, the mitochondrial activation, and the miRNA expression.

\section{METHODS}

\section{Subjects}

Seven healthy women of childbearing age (mean age, $36.3 \pm$ 7.1 years old) who were generally used to a sedentary lifestyle (at $110 \mathrm{~m}$ altitude sea level, a.s.l.) were enrolled to serve as subjects to the study known as GOKYO KHUMBU/AMA DABLAM TREK 2012. None of these women suffered from any metabolic or skeletal muscle diseases. The women were not engaged in any specific trekking or exercise training protocols within a few months of their enrolment, except two of them who occasionally went trekking. All of the subjects provided written, informed consent before participating in the study. The study was conducted according to the Helsinki Declaration, and it was approved by Ethic Committee of "G. d'Annunzio" University of Chieti-Pescara, Italy (protocol no. 773 COET).

\section{Experimental Design and Training}

Trekking consisted of a 12- day walking at low-altitude on mountain paths in central Italy (L'Aquila, Abruzzo, Italy). The average altitude was $598 \mathrm{~m} \pm 561$ and a range of difference in elevation between consecutive days was $250-1000 \mathrm{~m}$. The total covered distance was $139600 \mathrm{~m}$. The total ascent and descent 


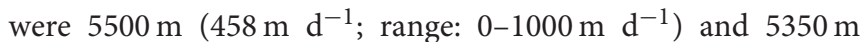
(445 $\mathrm{m} \mathrm{d}^{-1}$; range: $0-1000 \mathrm{~m} \mathrm{~d}^{-1}$ ), respectively. The total walking time was $149580 \mathrm{~s} \pm 27.06$, on average $3 \mathrm{~h}$ and $28 \mathrm{~min}$ per day, and the average speed was $0.93 \mathrm{~m} \mathrm{~s}^{-1}$. The total number of steps was $182372 \pm 77.43$. The volunteers freely choose their intensity of exercise also considering the general recommendations to approach physical exercise with a load adapted to personal capacity (guidelines of American College Sport Medicine, Garber et al., 2011). The exercise intensity of the training was monitored with a heart rate monitor for each subject (POLAR ${ }^{\circledR}$, Kempele, Finland). The average heart rate of the seven subjects in the 12 day of exercise training period was $111 \pm 10 \mathrm{bpm}$, which was classified as light-to-moderate intensity (Tam et al., 2015). The subjects did not perform other exercise outside the trekking protocol.

\section{Skeletal Muscle Needle Biopsy}

Tiny percutaneous needle biopsies from the vastus lateralis muscle were performed at the Laboratory of Functional Evaluation, "G. d'Annunzio" University of Chieti-Pescara, as described by Pietrangelo et al. (2011), a week before initiating the exercise training (PRE-Ex), and 9 days after the specific planned light-to-moderate exercise training at low altitude (POST-Ex). Specifically, after the training period, the subjects stayed at rest for a couple of days, then they were engaged in functional evaluations described in (Tam et al., 2015), that lasted 5 days, and after a couple of days of recovering, they had the needle biopsies.

\section{Satellite Cell Population and Myogenicity}

The satellite cells were obtained, expanded as myoblasts in growth medium, and differentiated as previously described (Fulle et al., 2005; Mancinelli et al., 2011). Briefly, the percentages of myogenicity of the cell cultures were obtained using an immunocytochemistry assay, with the marker desmin (Kaufman and Foster, 1988; Behr et al., 1994), and with biotinylated streptavidin-AP kits (LSAB + System-AP Universal kits; Cat. No. K0678; DAKO, Dakocytomation, Glostrup, Denmark). Differentiation of the cell populations was determined by counting the numbers of nuclei in the myotubes after 7 days of differentiation, as percentages with respect to the total number of nuclei, with the ratio between these two values (nuclei in myotubes/total nuclei $\times 100 \%)$ giving the Fusion Index. We only considered myotubes that were positive to the primary antibody against myosin heavy chain (MHC), using the MF20 anti-MHC monoclonal antibody (diluted 1:50; Developmental Studies Hybridoma Bank, University of Iowa, Iowa City, IA, USA), and that contained three or more nuclei (Pietrangelo et al., 2009).

\section{Intracellular Calcium Concentration Measurement}

The cells were loaded with Fura2-AM at the final concentration of $5 \mu \mathrm{M}$ for $30 \mathrm{~min}$, which was then de-esterificated for $20 \mathrm{~min}$ at $37^{\circ} \mathrm{C}$. The experiments were performed and images were acquired using the procedures and set-up described by Pietrangelo et al. (2002).

\section{Reactive Oxygen Species}

The general analysis of ROS, specifically the cellular peroxidation end products, was conducted using the dye 2,7-dichlorofluorescein diacetate (DCF; Cat.No. D6883; Sigma). The cells were plated and grown in 96-well microplates (1000 cells $\left.0.32 \mathrm{~cm}^{-1}\right)$, and incubated with $10 \mu \mathrm{M}$ DCF for $30 \mathrm{~min}$ at $37^{\circ} \mathrm{C}$ in sterile normal extracellular solution $(140 \mathrm{mM} \mathrm{NaCl}$, $2.8 \mathrm{mM} \mathrm{KCl}, 2 \mathrm{mM} \mathrm{CaCl} 2,2 \mathrm{mM} \mathrm{MgCl} 2,10 \mathrm{mM}$ glucose, $10 \mathrm{mM}$ Hepes, $\mathrm{pH}$ 7.3). The fluorescence of the dye accumulated in the cytoplasm (i.e., 2,7-dichlorofluorescein) was determined at $530 \mathrm{~nm}$ (excitation, $490 \mathrm{~nm}$ ) using a fluorometer (SPECTRAmax Gemini XS; Molecular Devices Toronto, ON, Canada). The analysis was conducted using the SOFTmax Pro software. The cells were stimulated with $100 \mathrm{nM}$ hydrogen peroxide $\left(\mathrm{H}_{2} \mathrm{O}_{2}\right)$ to evaluate their response to an oxidant (Menghini et al., 2011).

To determine the superoxide anion $\left(\mathrm{O}_{2}^{\bullet-}\right)$, we used an assay based on the dye nitroblue tetrazolium chloride (NBT; Cat. No. N6639; Sigma-Aldrich) and its reduction into formazan $\mathrm{O}_{2}^{\bullet-}$ (Sozio et al., 2013). The absorbance at $550 \mathrm{~nm}$ was determined using a spectrophotometer (SPECTRAmax 190 microplate 257; Molecular Devices, Sunnyvale, CA, USA), such that the greater the $\mathrm{O}_{2}^{\bullet-}$ level, the greater the absorbance. The cells $\left(1 \times 10^{6}\right.$ cells $)$ were detached, centrifuged at $170 \times g$ for $5 \mathrm{~min}$, resuspended in $1 \mathrm{ml} \mathrm{NBT}$ at $1 \mathrm{mg} \mathrm{ml}^{-1}$ in $0.9 \%$ aqueous $\mathrm{NaCl}$, and incubated for $3 \mathrm{~h}$ at $37^{\circ} \mathrm{C}$. Then, the cells were centrifuged at $100 \times g$ for $10 \mathrm{~min}$, resuspended in $1 \mathrm{ml} \mathrm{DMSO}$, and left for $20 \mathrm{~min}$ at $37^{\circ} \mathrm{C}$. Finally, the NBT absorbance was determined.

\section{Transmembrane Mitochondrial Potential}

The mitochondrial membrane potential was determined using the JC-1 dye $\left(5,5^{\prime}, 6,6^{\prime}\right.$-tetracloro- $1,1^{\prime}, 3,3^{\prime}$ tetraethylbenzimidazolylcarbocianine iodide/chloride; Molecular Probes). JC-1 is a cationic dye that accumulates in the mitochondria. When the mitochondrial potential is high, as in normal cells, JC-1 aggregates into dimers that emit red fluorescence (aggregated J: excitation/ emission, $560 / 595 \mathrm{~nm}$ ). When the membrane potential is low, as in the presence of oxidative stress, JC-1 forms monomers that emit green fluorescence (excitation/emission, 488/522 nm), with concomitant decreased red fluorescence. The ratio of the red/green fluorescence depends exclusively on the mitochondrial potential, with no effects of other factors (such as mitochondrial dimension, volume, shape, or density). The cells were plated into 96-well plates, incubated with $10 \mu \mathrm{g}$ $\mathrm{ml}^{-1} \mathrm{JC}-1$ for $15 \mathrm{~min}$ at $37^{\circ} \mathrm{C}$, and assayed using a fluorometer (SPECTRAmax Gemini XS; Molecular Devices Toronto, ON, Canada) equipped with the SoftMax Pro software (Gemini XS, Molecular Devices Toronto, ON, Canada) (Nuydens et al., 1999). The fluorescence is reported as means \pm SEM of the red/green fluorescence ratios of samples with respect to control, as $\mathrm{f}(\mathrm{r} / \mathrm{g}) / \mathrm{f}(\mathrm{r} / \mathrm{g})_{\mathrm{c}}$ (Morabito et al., 2010), and is here given as $\Delta \Psi_{\text {mit. }}$ The dye ratio for JC-1 between the inner and outer mitochondrial membrane potentials was related to the mitochondrial depolarization after an oxidant insult, such as with $\left(\mathrm{H}_{2} \mathrm{O}_{2}\right)$. 


\section{Antioxidant Enzyme Activity}

The antioxidant enzymes analyzed were superoxide dismutase and catalase, The assays were performed using the cells cytosolic fraction.

\section{Superoxide Dismutase}

The activity of superoxide dismutase (SOD) is direct against $\mathrm{O}_{2}^{\bullet-}$. SOD catalyzes a disproportionation reaction where a first $\mathrm{O}_{2}^{\circ-}$ is oxidized and the second molecule is reduced, turning two molecules of superoxide into $\mathrm{O}_{2}$ and $\mathrm{H}_{2} \mathrm{O}_{2}$. The enzymatic activity was determined according to Fulle et al. (2000) The final assay volume was $1 \mathrm{ml}$ and contained $20 \mathrm{mM} \mathrm{Na}_{2} \mathrm{CO}_{3}$ buffer $\mathrm{pH}$ 10, $10 \mathrm{mM}$ Cytochrome c, $1 \mathrm{mM}$ Xanthine and Xanthine Oxidase. Xanthine-xanthine oxidase is the $\mathrm{O}_{2}^{\bullet-}$ generation system. As the xanthine oxidase activity varies, the amount used for the assay was such that produced a rate of cytochrome $\mathrm{c}$ reduction, at $550 \mathrm{~nm}$, of 0.025 per minute without SOD addiction. The assay was performed at $550 \mathrm{~nm}$ for $10 \mathrm{~min}$. The SOD units were calculated considering that 1 SOD unit is defined as the quantity that inhibits the rate of cytochrome $\mathrm{c}$ reduction by $50 \%$.

\section{Catalase}

The reaction for which catalase (Cat) is best known is the "catalatic" reaction, in which $\mathrm{H}_{2} \mathrm{O}_{2}$ oxidizes the heme iron of the resting enzyme to form an oxyferryl group with a $\pi$-cationic porphyrin radical (Kirkman and Gaetani, 2006). This step is followed by oxidation of a second molecule of $\mathrm{H}_{2} \mathrm{O}_{2}$. Catalase forms two molecules of $\mathrm{H}_{2} \mathrm{O}$ and $\mathrm{O}_{2}$, starting from two molecules of $\mathrm{H}_{2} \mathrm{O}_{2}$. Catalase activity was determined, according to Greenwald (1985), by the decrease in absorbance due to $\mathrm{H}_{2} \mathrm{O}_{2}$ consumption $\left(\varepsilon=-0.04 \mathrm{mM}^{-1} \mathrm{~cm}^{-1}\right)$ measured at $240 \mathrm{~nm}$. The final reaction volume was $1 \mathrm{ml}$ and contained $100 \mathrm{mM}$ Na-phosphate buffer $\mathrm{pH} 7.0,12 \mu \mathrm{M} \mathrm{H}_{2} \mathrm{O}_{2}$ and $70 \mu \mathrm{g}$ of sample proteins. The reaction was followed for $1 \mathrm{~min}$ and the Cat activity was expressed in $\mu \mathrm{mol} / \mathrm{minute} / \mathrm{mg}$ proteins.

\section{miRNA Expression}

PureLink miRNA Isolation kits were used for the miRNA extractions (Cat. No. K1570-01, Invitrogen, Life Technologies, Molecular Devices, Sunnyvale, USA). About 800,000 cells were resuspended in $300 \mu \mathrm{l}$ binding buffer (from the PureLink miRNA kits), and $300 \mu l 70 \%$ alcohol was added to the lysate. This was forced into the spin cartridges of the PureLink miRNA Isolation kits, which were then centrifuged at 12000 $\times g$ for $1 \mathrm{~min}$. After washing with $100 \%$ alcohol, these were centrifuged again, as before. Then $500 \mu \mathrm{l}$ wash buffer was added to the spin cartridges, which were centrifuged again at $12000 \times g$ for $1 \mathrm{~min}$. This procedure was performed twice, and then the spin cartridges were centrifuged at $12000 \times g$ for $3 \mathrm{~min}$, to remove residual buffer. Finally, they were eluted with $50 \mu \mathrm{l}$ RNase-free sterile water. The RNA concentrations were determined using a NanoDrop ${ }^{\mathrm{TM}}$ spectrophotometer.

Retro-transcription and real-time PCR were carried out according to the Applied Biosystems TaqMan miRNA assay kit protocols. Briefly, the retro-transcription involved $20 \mathrm{ng}$ of a "small" RNA, as the "stem loop" primer that was specific for each miRNA, dNTPs, and inverse transcriptase RNAse inhibitors (according to the Applied Biosystems high capacity cDNA reverse transcription kit, part $\mathrm{N}^{\circ} 4368814$ ), using a thermocycler $\left(30 \mathrm{~min}\right.$ at $16^{\circ} \mathrm{C}, 30 \mathrm{~min}$ at $42^{\circ} \mathrm{C}, 5 \mathrm{~min}$ at $85^{\circ} \mathrm{C}$, then at $\left.4^{\circ} \mathrm{C}\right)$. Then, the real-time PCR for the miRNA expression levels was performed using TaqMan probes and specific TaqMan ${ }^{\circledR}$ Universal Master Mix II, without UNG, in 96-well plates (Part No.: 4440040, Applied Biosystems) with a sequence detection system (Applied Biosystems PRISM 7900 HT), in triplicate. MiR-16 was used as the endogenous control. The specific miRNA sequence probes used were (Applied Biosystems):

(i) has-miR-1 (UGGAAUGUAAAGAAGUAUGUAU; \#0022 22);

(ii) has-miR-206 (UGGAAUGUAAGGAAGUGUGUGG; \#00 0510);

(iii) has-miR-133b (UUUGGUCCCCUUCAACCAGCUA; \#00 2247);

(iv) has-miR-16-5p (UAGCAGCACGUAAAUAUUGGCG; \#00 0391).

The relative quantification of the miRNA targets was carried out using the $\Delta \mathrm{Ct}$ formula, according to the $\mathrm{Ct}$ method.

\section{Statistical Analysis}

The statistical analysis was carried out using GraphPad Prism Software, version 5 (GraphPad Software, La Jolla, CA, USA). The data are reported as means \pm standard error (SE). Unpaired and paired $t$-tests (for different group of cells and for the same cells with specific treatment, respectively) were used to reveal the statistical differences.

\section{RESULTS}

\section{Subjects}

Seven healthy women of childbearing age who were generally used to a sedentary life-style were enrolled to study the skeletal muscle regeneration potential after low to moderate intensity training as trekking at low altitude. Table 1 summarize their anthopometric and physiological features.

TABLE 1 | Anthropometric and physiological characteristics of the subjects before (PRE-Exercise) and after (POST-Exercise) 12-days training period.

\begin{tabular}{lcc}
\hline & PRE-exercise & POST-exercise \\
\hline $\mathrm{BW}(\mathrm{Kg})$ & $65.7 \pm 4.4$ & $65.1 \pm 4.0$ \\
$\mathrm{BMl}\left(\mathrm{Kg} \mathrm{m}{ }^{-2}\right)$ & $24.3 \pm 1.5$ & $24.1 \pm 1.4$ \\
$\mathrm{BF}(\%)$ & $27.2 \pm 2.6$ & $25.9 \pm 2.7$ \\
$\mathrm{VO}_{2 \max }\left(\mathrm{L} \mathrm{min}^{-1}\right)$ & $2.13 \pm 0.13$ & $2.16 \pm 0.12$ \\
\hline
\end{tabular}

BW, body weight; $B M I$, body mass index; $B F(\%)$, body fat percentage; $V_{2}$ max , maximum oxygen consumption. 
TABLE 2 | Characteristics of myogenicity and differentiation of the satellite cell populations isolated from the seven women after trekking in the Abruzzo hills (central Italy).

\begin{tabular}{|c|c|c|c|c|c|c|}
\hline \multirow{2}{*}{$\begin{array}{l}\text { Subject } \\
\text { code }\end{array}$} & \multicolumn{3}{|c|}{ PRE-exercise } & \multicolumn{3}{|c|}{ POST-exercise } \\
\hline & $\%$ Desmin $^{+}$ & Fusion Index (\%) & $\%$ Desmin + unfused & $\%$ Desmin + & Fusion Index (\%) & $\%$ Desmin ${ }^{+}$unfused \\
\hline$\# 1$ & 68.5 & 38.0 & 75.0 & 70.5 & 33.3 & 75.8 \\
\hline \#2 & 66.0 & 23.3 & 73.9 & 77.3 & 60.2 & 22.4 \\
\hline \#3 & 76.2 & 28.2 & 91.3 & 87.0 & 30.0 & 87.0 \\
\hline \#4 & 90.4 & 14.6 & 82.1 & 88.8 & 67.9 & 28.5 \\
\hline \#5 & 70.0 & 19.8 & 71.8 & 46.7 & 44.5 & 37.2 \\
\hline \#6 & 67.0 & 23.5 & 58.4 & 34.5 & 42.6 & 25.7 \\
\hline \#7 & 48.1 & 18.0 & 49.2 & - & - & - \\
\hline
\end{tabular}

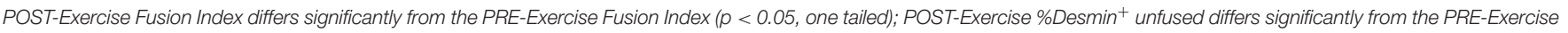
$\%$ Desmin $^{+}$unfused $(p<0.05$, one tailed).

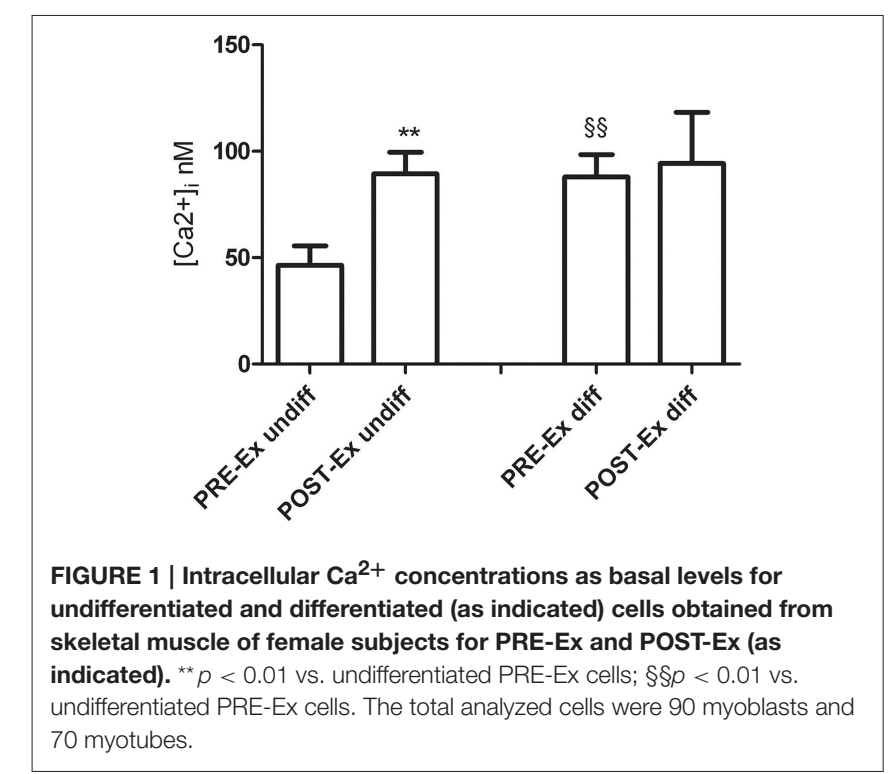

\section{Myogenic Characteristics and Analysis of Cell Differentiation After Exercise Training}

We obtained myogenic populations of adult stem cells, myoblasts, from percutaneous needle biopsies from the vastus lateralis muscle of female volunteers before (PRE-Ex) and after (POST-Ex) low altitude exercise training in the Abruzzo mountains. The characteristics of the cell differentiation are reported in Table 2 .

The analysis of desmin-positive undifferentiated cells suggested that there were no significant difference in the myogenicity between the PRE-Ex and POST-Ex conditions. Of note, the Fusion Index, which represents the percentage of myoblasts that can fuse over 7 days of differentiation forming myotubes, was significantly increased at POST-Ex $(p<0.05)$. The percentage of desmin-positive cells in the differentiation media (after 7 days of differentiation) significantly decreased $(p<0.05)$.

\section{Intracellular $\mathrm{Ca}^{2+}$ Concentrations of Cells}

Figure 1 shows the basal levels of the intracellular $\mathrm{Ca}^{2+}$ concentrations $\left(\left[\mathrm{Ca}^{2+}\right]_{\mathrm{i}}\right)$ of the undifferentiated and differentiated cells. The undifferentiated POST-Ex myoblasts had $\left[\mathrm{Ca}^{2+}\right]_{\mathrm{i}}$ that were significantly higher than PRE-Ex myoblasts $(p \leq 0.01)$. In the comparison of the differentiated PRE-Ex cells with respect to the undifferentiated PRE-Ex cells, these also showed an increase in $\left[\mathrm{Ca}^{2+}\right]_{\mathrm{i}}(p \leq 0.01)$. There were, however, no differences for the $\left[\mathrm{Ca}^{2+}\right]_{\mathrm{i}}$ between the differentiated and undifferentiated POST-Ex cells and among the differentiated ones.

\section{Superoxide Production and General Oxidation State}

The myoblasts showed different level of superoxide production (Table 3). While the myoblasts from subject \#1 maintained the same $\mathrm{O}_{2}^{\bullet-}$ levels, those from subjects \#2, \#3, and \#4 showed significant decreases ( $p \leq 0.0001)$; conversely, those from subjects \#5 and \#6 showed significant increases in $\mathrm{O}_{2}^{\bullet-}$ production $(p \leq 0.0001)$ after the exercise training. The increases in $\mathrm{O}_{2}^{\bullet-}$ production here were about $15 \%$ with respect to the control production, while the decreases ranged from 12 to $67 \%$ (Table 3).

The analysis of general oxidation state was conducted using DCF fluorescence. The addition of $100 \mathrm{nM} \mathrm{H}_{2} \mathrm{O}_{2}$ to the myoblasts loaded with DCF resulted in rapid increases in fluorescence that returned to basal level within $5 \mathrm{~min}$, in the samples with both decreased and increased $\mathrm{O}_{2}^{\bullet-}$ production (Figure 2). Of note, the POST-Ex cell populations showing reduced superoxide anion production showed also a less amount of ROS at basal level, as revealed by $10 \%$ less DCF fluorescence with respect to that measured at PRE-Ex, even if not significant. In fact, the DCF fluorescence of POST-Ex vs. PRE-Ex at $0 \mathrm{~min}$ was $5.4 \pm 0.7$ vs. $6.0 \pm 0.9$ (Figure 2, confront Figure 2B vs. Figure 2A). The POST-Ex myoblasts showing increased superoxide anion production showed similar amounts of DCF fluorescent dye with respect to the PRE-Ex ( $4.6 \pm 0.6$ vs. $4.3 \pm$ 0.7, not significant, Figures 2C,D).

\section{Antioxidant Enzyme Activity}

The activity of antioxidant enzymes Superoxide dismutase and Catalase were determined on cytosolic fractions of PRE-Ex and POST-Ex undifferentiated cells both in population with reduced and increased superoxide anion production (Figure 3). The myoblasts with increased $\mathrm{O}_{2}^{\bullet-}$ production (empty bars) showed no variation of both enzyme activity while those with decreased 

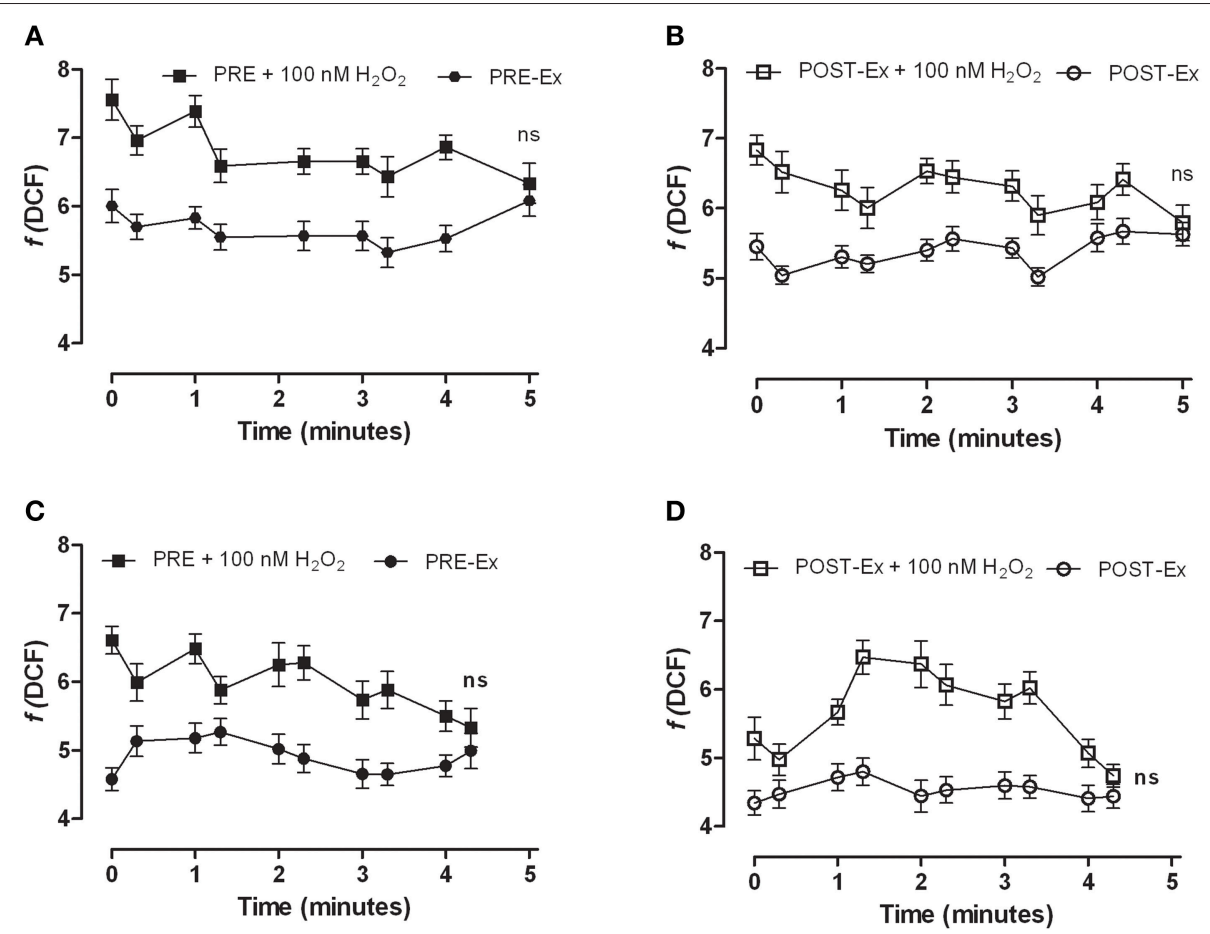

FIGURE 2 | Kinetics of DCF fluorescence in the control (PRE-Ex; A, C) and POST-Ex (B, D) myoblasts obtained from the skeletal muscle of the women that saw both decreased (A, B) and increased (C, D) $\mathrm{O}_{2}^{--}$production, without and with addition of $100 \mathrm{nM} \mathrm{H}_{2} \mathrm{O}_{2}$ (as indicated). The $\mathrm{H}_{2} \mathrm{O}_{2}$ was added at 0 min in dedicated samples $\left(+100 \mathrm{nM} \mathrm{H}_{2} \mathrm{O}_{2}\right)$. Data came from three independent experiments. All of the $\pm \mathrm{H}_{2} \mathrm{O}_{2}$ data points were significantly different $(p \leq 0.0001)$, except after 5 min ns, not significant.

TABLE 3 | Superoxide anion detection in the control (PRE-exercise) and after the low-moderate exercise conditioned (POST-exercise) satellite cells, as revealed by NBT dye fluorescence.

\begin{tabular}{llcc}
\hline \multirow{2}{*}{ Subject } & \multicolumn{2}{l}{ NBT dye fluorescence $($ mean \pm SD) } & \multirow{2}{*}{ Variation $^{\mathrm{a}(\%)}$} \\
\cline { 2 - 3 } & PRE-exercise & POST-exercise & \\
\hline$\# 1$ & $0.170 \pm 0.030$ & $0.180 \pm 0.011$ & 0 \\
$\# 2$ & $0.132 \pm 0.012$ & $0.114 \pm 0.006 \S \S$ & -14 \\
$\# 3$ & $0.139 \pm 0.004$ & $0.045 \pm 0.001 \S \S$ & -67 \\
$\# 4$ & $0.080 \pm 0.004$ & $0.070 \pm 0.002 \S \S$ & -12.5 \\
$\# 5$ & $0.060 \pm 0.002$ & $0.070 \pm 0.003 \S \S$ & +16 \\
$\# 6$ & $0.106 \pm 0.003$ & $0.125 \pm 0.004 \S \S$ & +18 \\
\hline
\end{tabular}

${ }^{a}$ percentage of variation with respect to PRE-Ex data (assumed as 100\%), § significantly decreased or increased $\mathrm{O}_{2}^{--}$radical level for POST-Ex vs. PRE-Ex $(p<0.001)$.

$\mathrm{O}_{2}^{\bullet-}$ production (dotted bars) showed a significant reduction of Superoxide dismutase activity $(p \leq 0.05)$ and no significant change of Catalase activity.

\section{Transmembrane Mitochondrial Potential}

The undifferentiated and differentiated PRE-Ex and POST-Ex cells showed stable transmembrane mitochondrial potentials (measured as the $\mathrm{f}[\mathrm{r} / \mathrm{g}] / \mathrm{f}[\mathrm{r} / \mathrm{g}]_{c}$ ratio for JC-1; $\Delta \Psi_{\text {mit }}$ ), which was reversibly depolarized (in a range of 10-20\%) under the oxidative stimulus of $100 \mathrm{nM} \mathrm{H}_{2} \mathrm{O}_{2}$ (data not shown). Acute stimulation with the $\mathrm{H}_{2} \mathrm{O}_{2}$ induced less mitochondrial depolarization of the POST-Ex myotubes than was seen PREEx, even if the depolarization levels were not significantly different (data not shown). The transmembrane mitochondrial potential of the myoblasts producing more superoxide anion provided an exception here: the PRE-Ex $\Delta \Psi_{\text {mit }}$ showed $\mathrm{H}_{2} \mathrm{O}_{2}$ dependent depolarization, as previously described, while the POST-Ex $\Delta \Psi_{\text {mit }}$ was stable with this addition of $\mathrm{H}_{2} \mathrm{O}_{2}$ (Figure 4).

\section{Epigenetic Profile Induced by Exercise Training}

The analysis of the expression of miRNAs in the POSTEx myoblasts showed an up-regulation of miR-1, miR133b, and miR206 respect to PRE-Ex in samples with decreased $\mathrm{O}_{2}^{\bullet-}$ production conversely we found a down-regulation of all miRNAs tested in samples with increased $\mathrm{O}_{2}^{\circ-}$ production (Figure 5).

\section{DISCUSSION}

We have analyzed here skeletal muscle regeneration in adult women after low-to-moderate exercise training with specific attention paid to oxidative status. Recently, molecular studies in humans, highlighted that fusion of myogenic cells is triggered by endurance exercise-induced muscle plasticity (Frese et al., 2015) 

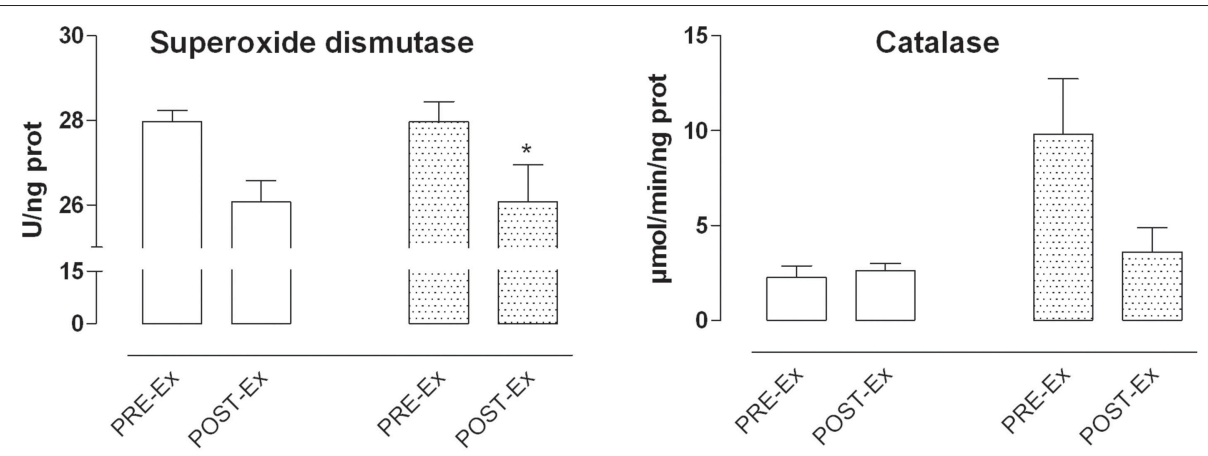

FIGURE 3 | Superoxide dismutase and Catalase activity. In the Figure is shown a representative example of enzyme activities. The activity of Superoxide dismutase showed similar level on myoblasts with decreased $\mathrm{O}_{2}^{\bullet-}$ production (empty bars) while it was reduced in myoblasts showing increased $\mathrm{O}_{2}^{\bullet-}$ production (dotted bars) with respect to PRE-Ex ( $\left.{ }^{*} p \leq 0.05\right)$. The Catalase activity was similar among the PRE-Ex and POST-Ex cells, despite the O ${ }_{2}^{\bullet-}$ production.

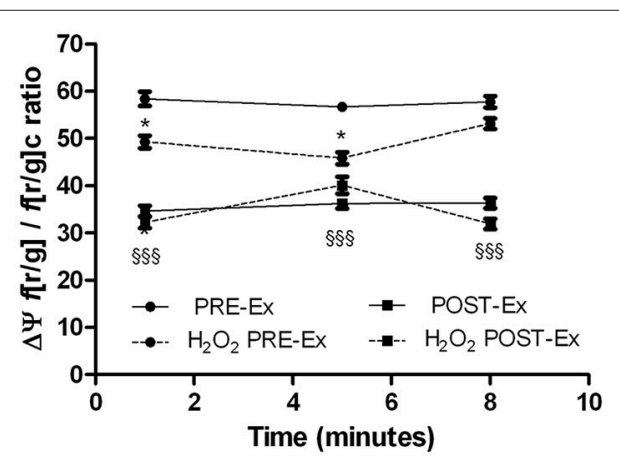

FIGURE 4 | Kinetics of the JC1 red/green fluorescence ratio variations as indirect measures of the transmembrane mitochondrial potential $(\Delta \Psi)$ of myotubes obtained from skeletal muscle of female subjects for PRE-Ex and POST-Ex, without and with addition of $100 \mathrm{nM} \mathrm{H}_{2} \mathrm{O}_{2}$ (as indicated). Data came from three independent experiments. The treatment with $\mathrm{H}_{2} \mathrm{O}_{2}$ produced significant $\Delta \Psi$ variation only in PRE-Ex cells ( ${ }^{*} p \leq 0.05$ ). The condition PRE-Ex vs. POST-Ex resulted significant only in untreated cells $(\S \S \S, p \leq 0.0001)$.

At the cellular level, the fusion process is characterized by the alignment/fusion of myoblast membranes and cytoskeleton/cytoplasm rearrangements which results in the formation of nascent myotubes. Many studies of in vitro skeletal myogenesis have shown that myoblast fusion is regulated by calcium-increase in myoblasts before myotube formation (Constantin et al., 1996). We recorded an increased $\left[\mathrm{Ca}^{2+}\right]_{\mathrm{i}}$ in the POST-Ex myoblats that could be at the base of their increased ability to fuse to each other to form myotubes (Antigny et al., 2014). In fact, the fusion index significantly increased after the exercise training (POST-Ex) despite the $\mathrm{O}_{2}^{\bullet-}$ production, along with a trend to a reduction in the levels of desmin-positive cells that did not fuse in the differentiation media.

The data from the literature are consistent with the observation that intracellular ROS generation by contracting skeletal muscle increases by two-four-fold during contraction (Jackson et al., 2007). These ROS are derived through different biochemical pathways, and in particular by mitochondrial activity.
In fact, during aerobic training, the enzymatic activity of this electron transfer shifts from complex IV to complex III (maximal ADP-stimulated respiration), which improves the efficiency of the mitochondria for the production of ATP and the reduction of $\mathrm{O}_{2}^{\bullet-}$ (Di Meo and Venditti, 2001; Muller et al., 2004; Kozlov et al., 2005; Quinlan et al., 2013).

The results here for the satellite cell populations obtained after this low altitude exercise training suggested that the exercise linked to training provoked redox imbalance in some manner, mainly reducing $\mathrm{O}_{2}^{\bullet-}$ production. These data thus showed that in the satellite cell populations of three of the six subjects there was significantly reduced $\mathrm{O}_{2}^{\bullet-}$ production, for one of the six there was no change, and for two of the six there was about a $15 \%$ increase in the $\mathrm{O}_{2}^{\bullet-}$ production, as a relatively small amount. Albeit the myoblasts from two subjects increased cellular $\mathrm{O}_{2}^{\bullet-}$ production, this was linked to reduced superoxide dismutase activity. This reduction could be due to both the involvement of the enzyme in the oxidant reduction activity or in the partial inhibition of the dismutase enzyme.

The ROS species produced physiologically during exercise can stimulate important physiological mechanisms. For instance, there can be reversible oxidation of exposed protein thiols of the amino-acid cysteine in the ryanodine receptor, which governs correct excitation-contraction coupling (Fulle et al., 2007). Other examples include stimulation of mitochondrial biogenesis (Powers et al., 2011), upregulation of antioxidant defenses (Gomez-Cabrera et al., 2008), expression of several genes for muscle hypertrophy (Powers et al., 2010), management of optimum muscle contractility (Reid et al., 1985), and muscle fatigue (Morillas-Ruiz et al., 2005).

Moreover, the data on general cellular peroxidation performed using DCF fluorescence, revealed that the presence of increased $\mathrm{O}_{2}^{\bullet-}$ production did not match with an establishment of oxidative stress. In fact, the POST-Ex cell populations showing increased $\mathrm{O}_{2}^{\bullet-}$ production, showed similar amount of DCF fluorescence with respect to PRE-Ex while those with reduced $\mathrm{O}_{2}^{\bullet-}$ production showed about $10 \%$ less amounts of the fluorescent dye DCF with respect to the PRE-Ex, albeit 

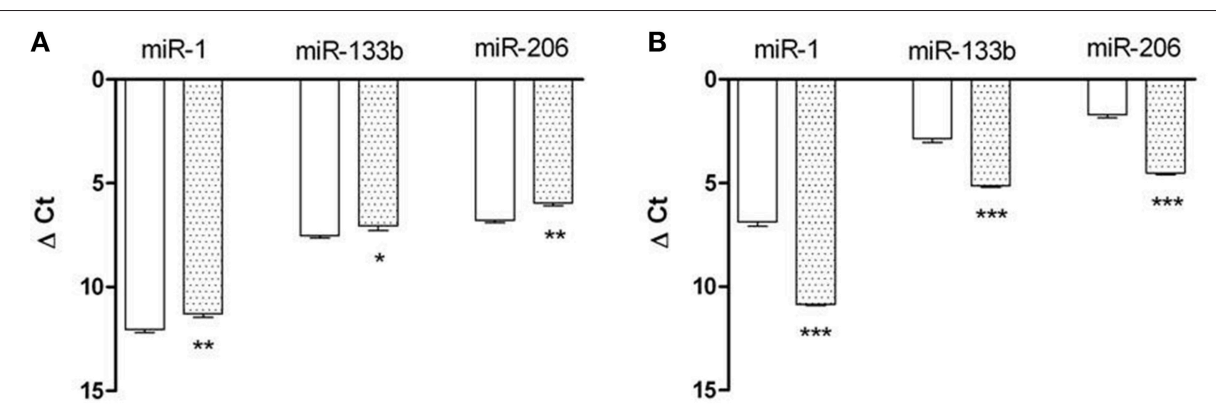

FIGURE 5 | Epigenetic signatures of miRNA expression. Relative expression of miR-1, miR-133b, and miR-206 (as indicated) in undifferentiated cells obtained from skeletal muscle of female subjects that saw both decreased (A) and increased (B) $\mathrm{O}_{2}^{\bullet-}$ production before (empty bars) and after (dotted bars) exercise training. Data came from three independent experiments, each performed in triplicate. ${ }^{\star}, p<0.05 ;{ }^{\star \star}, p<0.01 ;{ }^{\star \star \star}, p<0.0001$.

it not reached significant statistical differences. After the addition of $\mathrm{H}_{2} \mathrm{O}_{2}$ as external oxidant to mimic acute oxidative stress, all the cells completely reduced the ROS at the control levels in $5 \mathrm{~min}$, as shown by the kinetics of DCF fluorescence.

The $\mathrm{O}_{2}^{\bullet-}$ radical is rapidly converted into the cell by the superoxide dismutases, to the more stable $\mathrm{H}_{2} \mathrm{O}_{2}$ (Abele et al., 2002). This $\mathrm{H}_{2} \mathrm{O}_{2}$ then undergoes specific degradation by catalase (Sullivan-Gunn and Lewandowski, 2013). The measurement of Catalase activity showed no significant differences among cell populations despite the level of $\mathrm{O}_{2}^{--}$production, suggesting that probably the cells did not undergo the oxidative stress. The mitochondria are the main source of $\mathrm{O}_{2}^{--}$production; in addition there are other intracellular sources, such as the sarcoplasmic reticulum-associated and plasma-membraneassociated $\mathrm{NAD}(\mathrm{P}) \mathrm{H}$ oxidases, whereby the latter release $\mathrm{O}_{2}^{\bullet-}$ mainly into the extracellular space, so they would be less important for intracellular $\mathrm{O}_{2}^{\bullet-}$ production. Although we cannot exactly distinguish the sources of increased $\mathrm{O}_{2}^{\circ-}$ in our samples, we think that it could depend on the decreased superoxide dismutase activity and not on the impaired electron transfer shifts from mitochondrial complexes. In fact, the analysis of the mitochondrial transmembrane potential, $\Delta \Psi_{\text {mit }}$, suggested that the cell populations with decreased superoxide production after the exercise training showed the same levels of $\Delta \Psi_{\text {mit }}$ under the PRE-Ex and POST-Ex conditions. Acute stimulation with the $\mathrm{H}_{2} \mathrm{O}_{2}$ induced less mitochondrial depolarization of the POST-Ex myotubes than was seen PRE-Ex, which demonstrates potentially more efficient mitochondrial regulation. The investigation of $\Delta \Psi_{\text {mit }}$ in the cell populations with increased superoxide production showed that albeit some POST-Ex myotubes were more depolarized than their PRE-Ex controls, the depolarizing insult with $\mathrm{H}_{2} \mathrm{O}_{2}$ did not provoke further variations. It could be that these mitochondrial potential were fixed as in a protective asset (Starkov, 1997). This might be linked to the effectiveness of the exercise training, which would adapt the myotubes to counteract oxidation-dependent depolarization and thus avoid its eventual negative consequences. In this manner, the mitochondrial functionality and the ATP production would remain optimal.
The miRNA analysis of myoblasts revealed a particular signature of this low-to-moderate training at low altitude in relation to the oxidant production. In fact, the increased accumulation of $\mathrm{O}_{2}^{\bullet-}$ in myoblasts occurred along with down-regulation of miR-1, miR-133b, and miR-206 expression while these miRNAs were up-regulated in samples with increased $\mathrm{O}_{2}^{\bullet-}$ production. miR-1 pushes cells toward apoptosis by inhibiting the heat shock proteins 60 and 70 which inhibit the mitochondrial apoptosis pathway, miR-133 acts in an opposite way through the repression of caspase nine. Interestingly, the coherent up- or down-regulation of miR-1 and miR-133b, as found in all our samples despite the $\mathrm{O}_{2}^{\bullet-}$ production, suggested that apoptosis was switched off (Xu et al., 2007). Moreover, we noted that when miRNA-1, miRNA-133b and miRNA-206 were up-regulated the cells showed decreased level of $\mathrm{O}_{2}^{\bullet-}$ production, on the contrary when down-regulated, increased level of $\mathrm{O}_{2}^{\circ-}$ production. It could be possible that in female human myoblasts these miRNAs are specifically sensible to $\mathrm{O}_{2}^{\bullet-}$ presence. Moreover, the down-regulation of miRNA-1, miRNA-133b, and miRNA-206 has been correlated with skeletal muscle inflammatory (Georgantas et al., 2014). We think that in this muscle condition among oxidant species it could be present increased $\mathrm{O}_{2}^{\bullet-}$ production that could be responsible for these miRNA regulation and this scenario could be managed during female low training intensity session.

\section{CONCLUSIONS}

The low to moderate intensity training has been able to stimulate the regeneration of female skeletal muscle. It induced mainly a decrease of $\mathrm{O}_{2}^{\bullet-}$ production, an increase of human myoblasts fusion index along with $\left[\mathrm{Ca}^{2+}\right]_{i}$ increase. The $\mathrm{O}_{2}^{\circ-}$ production could regulate the miRNA-1, miRNA $133 \mathrm{~b}$, and miRNA-206 expression without affecting the myoblast differentiation.

\section{AUTHOR CONTRIBUTIONS}

TP designed the project, realised calcium imaging experiments, wrote the manuscript, analyzed and discussed the data. 
ED performed experiments on oxidative status and miRNA regulation. RM managed cell cultures, performed experiments on oxidative status, analyzed and discussed the data. CD trained the volunteers and discussed the data. AR performed experiments on oxidative status. GF discussed the data. SF analyzed and discussed the data.

\section{REFERENCES}

Abele, D., Heise, K., Pörtner, H. O., and Puntarulo, S. (2002). Temperature dependence of mitochondrial function and production of reactive oxygen species in the intertidal mud clam Mya arenaria. J. Exp. Biol. 205, 1831-1841.

Abruzzo, P. M., Esposito, F., Marchionni, C., di Tullio, S., Belia, S., Fulle, S., et al. (2013). Moderate exercise training induces ROS-related adaptations to skeletal muscles. Int. J. Sports Med. 34, 676-687. doi: 10.1055/s-0032-1323782

Antigny, F., Konig, S., Bernheim, L., and Frieden, M. (2014). Inositol 1,4,5 trisphosphate receptor 1 is a key player of human myoblast differentiation. Cell Calcium 56, 513-521. doi: 10.1016/j.ceca.2014.10.014

Appell, H. J., Forsberg, S., and Hollmann, W. (1988). Satellite cell activation in human skeletal muscle after training: evidence for muscle fiber neoformation. Int. J. Sports Med. 9, 297-299. doi: 10.1055/s-2007-1025026

Baar, K. (2014). Nutrition and the adaptation to endurance training. Sports Med. 44(Suppl. 1), S5-S12. doi: 10.1007/s40279-014-0146-1

Behr, T., Fischer, P., Müller-Felber, W., Schmidt-Achert, M., and Pongratz, D. (1994). Myofibrillogenesis in primary tissue cultures of adult human skeletal muscle: expression of desmin, titin, and nebulin. Clin. Investig. 72, 150-155. doi: 10.1007/BF00184594

Bernareggi, A., Luin, E., Formaggio, E., Fumagalli, G., and Lorenzon, P. (2012). Novel role for prepatterned nicotinic acetylcholine receptors during myogenesis. Muscle Nerve 46, 112-121. doi: 10.1002/mus.23284

Ceafalan, L. C., Popescu, B. O., and Hinescu, M. E. (2014). Cellular players in skeletal muscle regeneration. BioMed Res. Int. 2014:957014. doi: $10.1155 / 2014 / 957014$

Constantin, B., Cognard, C., and Raymond, G. (1996). Myoblast fusion requires cytosolic calcium elevation but not activation of voltage-dependent calcium channels. Cell Calcium 19, 365-374. doi: 10.1016/S0143-4160(96)90109-8

Crippa, S., Cassano, M., and Sampaolesi, M. (2012). Role of miRNAs in muscle stem cell biology: proliferation differentiation and death. Curr. Pharm. Des. 18, 1718-1729. doi: 10.2174/138161212799859620

Cumming, K. T., Raastad, T., Holden, G., Bastani, N. E., Schneeberger, D., Paronetto, M. P., et al. (2014). Effects of vitamin C and E supplementation on endogenous antioxidant systems and heat shock proteins in response to endurance training. Physiol. Rep. 2:e12142 doi: 10.14814/phy2.12142

Di Meo, S., and Venditti, P. (2001). Mitochondria in exercise-induced oxidative stress. Biol. Signals Recept. 10, 125-140. doi: 10.1159/000046880

Eisenberg, I., Alexander, M. S., and Kunkel, L. M. (2009). miRNAS in normal and diseased skeletal muscle. J. Cell. Mol. Med. 13, 2-11. doi: 10.1111/j.15824934.2008.00524.x

Fisher-Wellman, K., and Bloomer, J. (2009). Acute exercise and oxidative stress: a 30 year history. Dyn. Med. 8:1. doi: 10.1186/1476-5918-8-1

Frese, S., Ruebner, M., Suhr, F., Konou, T. M., Tappe, K. A., Toigo, M., et al. (2015). Long-term endurance exercise in humans stimulates cell fusion of myoblasts along with fusogenic endogenous retroviral genes in vivo. PLoS ONE 10:e0132099. doi: 10.1371/journal.pone.0132099

Fulle, S., Di Donna, S., Puglielli, C., Pietrangelo, T., Beccafico, S., Bellomo, R., et al. (2005). Age-dependent imbalance of the antioxidative system in human satellite cells. Exp. Gerontol. 40, 189-197. doi: 10.1016/j.exger.2004.11.006

Fulle, S., Mecocci, P., Fanó, G., Vecchiet, I., Vecchini, A., Racciotti, D., et al. (2000). Specific oxidative alterations in vastus lateralis muscle of patients with the diagnosis of chronic fatigue syndrome. Free Radic. Biol. Med. 29, 1252-1259. doi: 10.1016/S0891-5849(00)00419-6

Fulle, S., Pietrangelo, T., Mancinelli, R., Saggini, R., and Fanò, G. (2007). Specific correlations between muscle oxidative stress and chronic fatigue syndrome: a

\section{ACKNOWLEDGMENTS}

The authors would like to thank all of the volunteers for their collaboration. This study was funded by a "G. d'Annunzio" University grant, the 2012N8YJC3_003 and the 2010R8JK2X_007 PRIN national grants to PT and SF, respectively; the RBFR12BUMH_005 FIRB national grant to MR.

working hypothesis. J. Muscle Res. Cell Motil. 28, 355-362. doi: 10.1007/s10974008-9128-y

Garber, C. E., Blissmer, B., Deschenes, M. R., Franklin, B. A., Lamonte, M. J., Lee, I. M., et al. (2011). American college of sports medicine position stand. Quantity and quality of exercise for developing and maintaining cardiorespiratory, musculoskeletal, and neuromotor fitness in apparently healthy adults: guidance for prescribing exercise. Med. Sci. Sports Exerc. 43, 1334-1359. doi: 10.1249/MSS.0b013e318213fefb

Georgantas, R. W., Streicher, K., Greenberg, S. A., Greenlees, L. M., Zhu, W., Brohawn, P. Z., et al. (2014). Inhibition of myogenic microRNAs 1, 133, and 206 by inflammatory cytokines links inflammation and muscle degeneration in adult inflammatory myopathies. Arthritis Rheumatol. 66, 1022-1033. doi: 10.1002/art.38292

Gomez-Cabrera, M. C., Domenech, E., and Viña, J. (2008). Moderate exercise is an antioxidant: upregulation of antioxidant genes by training. Free Radic. Biol. Med. 44, 126-131. doi: 10.1016/j.freeradbiomed.2007.02.001

Green, P. S., and Simpkins, J. W. (2000). Neuroprotective effects of estrogens: potential mechanisms of action. Int. J. Dev. Neurosci. 18, 347-358. doi: 10.1016/S0736-5748(00)00017-4

Greenwald, R. A. (1985). Therapeutic benefits of oxygen radical scavenger treatments remain unproven. J. Free Radic. Biol. Med. 1, 173-177.

Gundersen, K. (2011). Excitation-transcription coupling in skeletal muscle: the molecular pathways of exercise. Biol. Rev. Camb. Philos. Soc. 86, 564-600. doi: 10.1111/j.1469-185X.2010.00161.x

Hindi, S. M., Tajrishi, M. M., and Kumar, A. (2013). Signaling mechanisms in mammalian myoblast fusion. Sci. Signal. 6:re2. doi: 10.1126/scisignal.2003832

Huang, Z.-P., Espinoza-Lewis, R., and Wang, D.-Z. (2012). Determination of miRNA targets in skeletal muscle cells. Methods Mol. Biol. Clifton N.J. 798, 475-490. doi: 10.1007/978-1-61779-343-1_28

Jackson, M. J., Pye, D., and Palomero, J. (2007). The production of reactive oxygen and nitrogen species by skeletal muscle. J. Appl. Physiol. 102, 1664-1670. doi: 10.1152/japplphysiol.01102.2006

Kadi, F., Charifi, N., Denis, C., Lexell, J., Andersen, J. L., Schjerling, P., et al. (2005). The behaviour of satellite cells in response to exercise: what have we learned from human studies? Pflugers Arch Eur. J. Physiol. 451, 319-327. doi: 10.1007/s00424-005-1406-6

Kadi, F., Johansson, F., Johansson, R., Sjöström, M., and Henriksson, J. (2004). Effects of one bout of endurance exercise on the expression of myogenin in human quadriceps muscle. J. Histochem. Cell Biol. 121, 329-334. doi: 10.1007/s00418-004-0630-z

Kaufman, S. J., and Foster, R. F. (1988). Replicating myoblasts express a musclespecific phenotype. Proc. Natl. Acad. Sci. U.S.A. 85, 9606-9610.

Kirkman, H. N., and Gaetani, G. F. (2006). Mammalian catalase: a venerable enzyme with new mysteries. Trends Biochem. Sci. 32, 44-50. doi: 10.1016/j.tibs.2006.11.003

Kozlov, A. V., Szalay, L., Umar, F., Koprik, K., Staniek, K., Niedermuller, H., et al. (2005). Skeletal muscles, heart, and lung are the main sources of oxygen radicals in old rats. Biochim. Biophys. Acta 1740, 382-389. doi: 10.1016/j.bbadis.2004.11.004

Kvorning, T., Kadi, F., Schjerling, P., Andersen, M., Brixen, K., Suetta, C., et al. (2014). The activity of satellite cells and myonuclei following 8 weeks of strength training in young men with suppressed testosterone levels. Acta Physiol. (Oxf). 213, 676-687. doi: 10.1111/apha.12404

Kwon, C., Han, Z., Olson, E. N., and Srivastava, D. (2005). MicroRNA1 influences cardiac differentiation in Drosophila and regulates Notch signaling. Proc. Natl. Acad. Sci. U.S.A. 102, 18986-18991. doi: 10.1073/pnas.0509535102 
La Rovere, R. M., Quattrocelli, M., Pietrangelo, T., Di Filippo, E. S., Maccatrozzo, L., Cassano, M., et al. (2014). Myogenic potential of canine craniofacial satellite cells. Front. Aging Neurosci. 6:90. doi: 10.3389/fnagi.2014.00090

Lorenzon, P., Bandi, E., de Guarrini, F., Pietrangelo, T., Schäfer, R., Zweyer, M., et al. (2004). Ageing affects the differentiation potential of human myoblasts. Exp. Gerontol. 39, 1545-1554. doi: 10.1016/j.exger.2004.07.008

Mancinelli, R., Pietrangelo, T., La Rovere, R., Toniolo, L., Fanò, G., Reggiani, C., et al. (2011). Cellular and molecular responses of human skeletal muscle exposed to hypoxic environment. J. Biol. Regul. Homeost. Agents 25, 635-645.

McCarthy, J. J., and Esser, K. A. (2007). MicroRNA-1 and microRNA-133a expression are decreased during skeletal muscle hypertrophy. J. Appl. Physiol. 102, 306-313. doi: 10.1152/japplphysiol.00932.2006

Mecocci, P., Fanó, G., Fulle, S., MacGarvey, U., Shinobu, L., Polidori, M. C., et al. (1999). Age-dependent increases in oxidative damage to DNA, lipids and proteins in human skeletal muscle. Free Radic. Biol. Med. 26, 303-308. doi: 10.1016/s0891-5849(98)00208-1

Menghini, L., Leporini, L., Scanu, N., Pintore, G., La Rovere, R., Di Filippo, E. S., et al. (2011). Effect of phytochemical concentrations on biological activities of cranberry extracts. J. Biol. Regul. Homeost. Agents 25, 27-35.

Millay, D. P., O’Rourke, J. R., Sutherland, L. B., Bezprozvannaya, S., Shelton, J. M., Bassel-Duby, R., et al. (2013). Myomaker is a membrane activator of myoblast fusion and muscle formation. Nature 499, 301-305. doi: 10.1038/nature12343

Morabito, C., Rovetta, F., Bizzarri, M., Mazzoleni, G., Fanò, G., and Mariggiò, M. A. (2010). Modulation of redox status and calcium handling by extremely low frequency electromagnetic fields in $\mathrm{C} 2 \mathrm{C} 12$ muscle cells: a real-time, single-cell approach. Free Radic. Biol Med. 48, 579-589. doi: 10.1016/j.freeradbiomed.2009.12.005

Morillas-Ruiz, J., Zafrilla, P., Almar, M., Cuevas, M. J., Lopez, F. J., bellan, P., et al. (2005). The effects of an anti-oxidant-supplemented beverage on exerciseinduced oxidative stress: results from a placebo-controlled double-blind study in cyclists. Eur. J. Appl. Physiol. 95, 543-549. doi: 10.1007/s00421-005-0017-4

Muller, F. L., Liu, Y., and Van Remmen, H. (2004). Complex III releases superoxide to both sides of inner mitochondrial membrane. J. Biol. Chem. 279, 49064-49073. doi: 10.1074/jbc.M407715200

Nikolaidis, M. G., Margaritelis, N. V., Paschalis, V., Theodorou, A. A., Kyparos, A., and Vrabas, I. S. (2015). "Common questions and tentative answers on how to assess oxidative stress after antioxidant supplementation and exercise," in Antioxidants in Sport Nutrition, ed M. Lamprecht (Boca Raton, FL: CRC Press).

Nuydens, R., Novalbos, J., Dispersyn, G., Weber, C., Borgers, M., and Geerts, H. (1999). A rapid method for the evaluation of compounds with mitochondriaprotective properties. J. Neurosci. Methods 92, 153-159. doi: 10.1016/S01650270(99)00107-7

Pietrangelo, T., D’Amelio, L., Doria, C., Mancinelli, R., Fulle, S., and Fanò, G. (2011). Tiny percutaneous needle biopsy: an efficient method for studying cellular and molecular aspects of skeletal muscle in humans. Int. J. Mol. Med. 27, 361-367. doi: 10.3892/ijmm.2010.582

Pietrangelo, T., Fioretti, B., Mancinelli, R., Catacuzzeno, L., Franciolini, F., Fanò, G., et al. (2006). Extracellular guanosine-5' -triphosphate modulates myogenesis via intermediate $\mathrm{Ca}(2+)$-activated $\mathrm{K}+$ currents in $\mathrm{C} 2 \mathrm{C} 12$ mouse cells. J. Physiol. 572, 721-733. doi: 10.1113/jphysiol.2005.102194

Pietrangelo, T., Mariggiò, M. A., Lorenzon, P., Fulle, S., Protasi, F., Rathbone, M., et al. (2002). Characterization of specific GTP binding sites in C2C12 mouse skeletal muscle cells. J. Muscle Res. Cell Motil. 23, 107-118. doi: 10.1023/A:1020288117082

Pietrangelo, T., Puglielli, C., Mancinelli, R., Beccafico, S., Fanò, G., and Fulle, S. (2009). Molecular basis of the Myogenic profile of aged human skeletal muscle satellite cells during differentiation. Exp. Geront. 44, 523-531. doi: 10.1016/j.exger.2009.05.002
Powers, S. K., Duarte, J., Kavazis, A. N., and Talbert, E. E. (2010). Reactive oxygen species are signaling molecules for skeletal muscle adaptation. Exp. Physiol. 95, 1-9. doi: 10.1113/expphysiol.2009.050526

Powers, S. K., Nelson, W. B., and Hudson, M. B. (2011). Exercise-induced oxidative stress in humans: cause and consequences. Free Radic. Biol. Med. 51, 942-950. doi: 10.1016/j.freeradbiomed.2010.12.009

Quinlan, C. L., Perevoshchikova, I. V., Hey-Mogensen, M., Orr, A. L., and Brand, M. D. (2013). Sites of reactive oxygen species generation by mitochondria oxidizing different substrates. Redox Biol. 1, 304-312. doi: 10.1016/j.redox.2013.04.005

Reid, M. B., Khawli, F. A., and Moody, M. R. (1985). Reactive oxygen in skeletal muscle. III. Contractility of unfatigued muscle. J. Appl. Physiol. 75, 1081-1087.

Shin, K. S., Park, J. Y., Ha, D. B., Chung, C. H., and Kang, M.-S. (1996). Involvement of KCa channels and stretch-activated channels in calcium influx, triggering membrane fusion of chick embryonic myoblasts. Dev. Biol. 175, 14-23. doi: 10.1006/dbio.1996.0091

Siens, H., and Cadenas, E. (1985). Oxidative stress: damage to intact cells and organs. Philos. Trans. R. Soc. Lond. Ser. B Biol. Sci. 311, 617-631. doi: 10.1098/rstb.1985.0168

Siens, H., and Jones, D. P. (2007). "Oxidative stress," in Encyclopedia of Stress, ed G. Fink (Victoria: Elsevier), 45-48.

Snijders, T., Verdijk, L. B., Beelen, M., McKay, B. R., Parise, G., Kadi, F., et al. (2012). A single bout of exercise activates skeletal muscle satellite cells during subsequent overnight recovery. Exp. Physiol. 97, 762-773. doi: 10.1113/expphysiol.2011.063313

Sozio, P., Cerasa, L. S., Laserra, S., Cacciatore, I., Cornacchia, C., Di Filippo, E. S., et al. (2013). Memantine-sulfur containing antioxidant conjugates as potential prodrugs to improve the treatment of Alzheimer's disease. Eur. J. Pharm. Sci. 49, 187-198. doi: 10.1016/j.ejps.2013.02.013

Starkov, A. A. (1997). "Mild" uncoupling of mitochondria. Biosci. Rep. 17, 273-279. doi: 10.1023/A:1027380527769

Sullivan-Gunn, M. J., and Lewandowski, P. A. (2013). Elevated hydrogen peroxide and decreased catalase and glutathione peroxidase protection are associated with aging sarcopenia. BMC Geriatr. 13:104. doi: 10.1186/1471-2318-13-104

Tam, E., Bruseghini, P., Calabria, E., Sacco, L. D., Doria, C., Grassi, B., et al. (2015). Gokyo Khumbu/Ama Dablam Trek 2012: effects of physical training and high-altitude exposure on oxidative metabolism, muscle composition, and metabolic cost of walking in women. Eur. J. Appl. Physiol. doi: 10.1007/s00421015-3256-z. [Epub ahead of print].

Verdijk, L. B. (2014). Satellite cells activation as a critical step in skeletal muscle plasticity. Exp. Physiol. 99, 1449-1450. doi: 10.1113/expphysiol.2014.081273

Verdijk, L. B., Snijders, T., Drost, M., Delhaas, T., Kadi, F., and van Loon, L. J. (2014). Satellite cells in human skeletal muscle; from birth to old age. Age 36, 545-547. doi: 10.1007/s11357-013-9583-2

Xu, C., Lu, Y., Pan, Z., Chu, W., Luo, X., Lin, H., et al. (2007). The musclespecific microRNAs miR-1 and miR-133 produce opposing effects on apoptosis by targeting HSP60, HSP70 and caspase-9 in cardiomyocytes. J. Cell Sci. 120(Pt 17), 3045-3052. doi: 10.1242/jcs.010728

Conflict of Interest Statement: The authors declare that the research was conducted in the absence of any commercial or financial relationships that could be construed as a potential conflict of interest.

Copyright (c) 2015 Pietrangelo, Di Filippo, Mancinelli, Doria, Rotini, Fanò-Illic and Fulle. This is an open-access article distributed under the terms of the Creative Commons Attribution License (CC BY). The use, distribution or reproduction in other forums is permitted, provided the original author(s) or licensor are credited and that the original publication in this journal is cited, in accordance with accepted academic practice. No use, distribution or reproduction is permitted which does not comply with these terms. 